www.czasopisma.marszalek.com.pl/pl/10-15804/npw

\author{
Oktawia Ewa Braniewicz
}

Uniwersytet Łódzki

ORCID ID: https://orcid.org/0000-0002-5453-0918

\title{
Między kulturą, wiarą a społeczeństwem [recenzja książki Religie i dziedzictwo kulturowe Azji]
}

Between culture, faith and society [book review Religie i dziedzictwo kulturowe Azji] Между культурой, верой и обществом [рецензия книги Religie i dziedzictwo kulturowe Azji]

\footnotetext{
zja od wieków fascynowała podróżników, pisarzy oraz naukowców. - Odmienna kultura, ciekawe rozwiązania ustrojowe oraz wierzenia, fascynowały reprezentantów różnych dziedzin naukowych. Co jakiś czas na rynku wydawniczym ukazuje się nowa pozycja dotycząca tego kontynentu. Jednym z przodujących wydawnictw, które specjalizuje się w wysokiej klasy monografiach poświęconych azjatyckiej problematyce jest toruńskie Wydawnictwo Adam Marszałek. W innowacyjnej serii wydawniczej „Biblioteka Azji i Pacyfiku” ukazywane są prace polskich i zagranicznych autorów, którzy propagują idee współpracy europejsko-azjatyckiej.

Religie i dziedzictwo kulturowe Azji to książka pod redakcją Joanny Marszałek-Kawy (autorki cenionych prac politologicznych, por. Marszałek-Kawa, 2016; Marszałek-Kawa, Plecka, 2018) i Bartosza Płotki. Dziesięciu badaczy zaproszonych do współpracy stworzyło niezwykle interesujące dzieło, którego lektura jest prawdziwą przyjemnością. Monografia liczy 215 stron i składa się z dziesięciu rozdziałów. Ich autorzy reprezentują odmienne dziedziny
} 
naukowe i różne ośrodki akademickie w Polsce, m.in. Uniwersytet Kardynała Stefana Wyszyńskiego w Warszawie, Uniwersytet Ekonomiczny w Krakowie czy też Wyższą Szkołę Przedsiębiorczości w Warszawie. Dzięki temu lektura Religii i dziedzictwa kulturowego Azji pozwala spojrzeć czytelnikowi na wskazaną problematykę z naprawdę szerokiej i różnorodnej perspektywy.

Dobór autorów do poszczególnych rozdziałów należy ocenić jednoznacznie pozytywnie, ponieważ znakomicie wykorzystano ich doświadczenie i wiedzę. Należy zauważyć, iż każdy rozdział może stanowić odrębną lekturę, bez konieczności czytania całej książki, co dla pewnej grupy odbiorców będzie niewątpliwie atutem. Jednak warto poświęcić czas i przeczytać wszystkich dziesięć rozdziałów, gdyż stanowią one spójną, kompleksową całość. Struktura recenzowanej książki jest dopracowana, klarowna, a przede wszystkim pozwala czytelnikowi swobodnie przeniknąć do zagadnień, terminologii i problematyki związanej z religią i dziedzictwem kulturowym Azji.

W pierwszym rozdziale Sergiusz Anoszko wprowadza nas w świat religii nowego wieku w Azji Południowo-Wschodniej, a konkretniej w zagadnienia dotyczące kodaizmu i jego znaczenia dla Wietnamczyków. Jest to tematyka niezwykle niszowa, którą pasjonaci azjatyckich wierzeń na pewno docenią. Agnieszka Latosińska opisuje działalność i główne założenia doktrynalne Niezależnego Kościoła Filipińskiego oraz ukazuje kontekst jego powstania. Atutem tego rozdziału są fotografie, które pozwalają czytelnikowi na pełną wizualizację przybliżanych zagadnień. Kazimierz Pierzchała w sposób niezwykle klarowny przeprowadza czytelników przez korelację wierzeń i teologii politycznej w Chinach. W tej części monografii odnajdziemy buddyzm, konfucjanizm, taoizm, chrześcijaństwo oraz specyfikę ortodoksji państwowej. Dominik Wróblewski przeanalizował szamanizm koreański, który ukazał jako religię harmonii, nierozerwalnie połączoną z kulturą duchową Koreańczyków. Szamanizm stanowi istotny element tradycji i tożsamości narodowej mieszkańców Półwyspu Koreańskiego. Janusz Mariański podjął się trudnych rozważań dotyczących sekularyzacji jako fenomenu europejskiego i światowego. Ów rozdział stanowi interesujące rozważania na temat kondycji religii we współczesnym świecie. Kolejna autorka, Laura Koba, zmierzyła się z problematyką uniwersalizmu praw człowieka w kontekście kulturowych i politycznych uwarunkowań Azji. Jest to niezwykle interesujący rozdział, który stanowi praktyczną część opisywanej monografii. 
Kontynuacją tej części jest rozdział autorstwa Agaty Strządały poświęcony bioetyce filipińskiej. Autorka postawiła śmiałą tezę o nieprzystępności idei globalnej bioetyki do realiów azjatyckich kręgów kulturowych. Bartosz Płotka jest autorem aż dwóch rozdziałów: pierwszy dotyczy nieformalnej zmiany tajskiej surogacji, a drugi politycznych aspektów aborcji w Polsce i Tajlandii. Na uwagę zasługuje ciekawy dobór źródeł oraz kontrowersyjny charakter wybranej tematyki.

Z całą stanowczością należy zaznaczyć, że jest to unikalne dzieło, które prezentuje różne aspekty religii i dziedzictwa kulturowego Azji. Jednym z walorów książki są mapy i fotografie, które znajdują się w wybranych rozdziałach. Dzięki nim czytelnik może spojrzeć na świat azjatycki i odkryć np. na czym polega wyjątkowość Kościoła katolickiego na Filipinach, jak wyglądają tamtejsze sklepy spożywcze oraz umiejscowić na mapie świata sporne wyspy Spratly. To ogromny atut książki, która poza dużą dawką merytorycznej wiedzy, zawiera także przekaz za pośrednictwem obrazów.

Moim zdaniem Religia i dziedzictwo kulturowe Azji jest obowiązkową pozycją dla każdego, kto interesuje się rejonem Azji i Pacyfiku, odmiennymi od europejskiej kulturą i wierzeniami. To lektura nie tylko dla specjalistów z zakresu nauk orientalnych, politologów, socjologów, czy też kulturoznawców, ale także dla studentów, doktorantów i każdego, kto interesuje się szeroko pojętą Azją. W mojej ocenie, niezależnie od wykształcenia, wykonywanej profesji czy też poziomu posiadanej wiedzy ogólnej, czytelnik będzie usatysfakcjonowany.

\section{MGR OKTAWIA EWA BRANIEWICZ}

Katedra Prawa Międzynarodowego i Stosunków Międzynarodowych

Wydział Prawa i Administracji

Uniwersytet Łódzki

ul. S. Kopcińskiego 8/12, 90-033 Łódź

oktawia28@op.pl 


\section{Bibliografia}

Marszałek-Kawa, J. (2016). The Institutional Position and Functions of the Sejm of the Republic of Poland after the Accession to the European Union. Torun: Wydawnictwo Adam Marszałek.

Marszałek-Kawa, J., Plecka, D. (red.). (2018). Leksykon wiedzy politologicznej. Toruń: Wydawnictwo Adam Marszałek.

Marszałek-Kawa, J., Płotka, B. (2018). Religie i dziedzictwo kulturowe Azji. Toruń: Wydawnictwo Adam Marszałek. 